\title{
The failure of the Dutch MINAS policy: a transaction cost analysis
}

\author{
S. A. L. Wright \\ Food and Resource Economics Institute, \\ Royal Veterinary and Agricultural University, Denmark
}

\begin{abstract}
The paper analyses the Dutch MINAS policy, a tax combined with nutrient accounting. Its aim was to reduce nitrate levels in groundwater from agriculture sources. MINAS was beset with problems from the outset. Therefore, the aim of the paper is to determine the reasons for the 'erosion' of the policy. The paper begins with a theoretical analysis of the design of the instrument, the conclusion being that, according to economic theory, the instrument appears to be well designed. Despite this, MINAS still experienced problems, which were so pervasive that the functioning of the instrument became seriously undermined. The paper identifies certain key events, specific problems with the design of MINAS, which resulted in some farmers receiving very high unjustified taxes, and external socio-economic pressures, which in combination fuelled widespread resistance to the policy and hence escalating transaction costs due to the increasingly large administrative burden. The paper concludes that whilst it may have been possible for policy makers to avoid some of the identified problems it is considered that the majority were beyond their control. However, it was perhaps inevitable from the outset that such a system would encounter problems due to the very high degree of precision that was attempted and thus policy makers could be criticised for not opting for a simpler system. The paper is critical of the application of a tax/nutrient accounting system to control nutrient leaching. The study is based on empirical research, specifically a series of interviews with key personnel within organizations linked with MINAS.
\end{abstract}

Keywords: policy erosion, MINAS, transaction costs, administrative costs, nitrate pollution, environmental tax, nutrient accounting. 


\section{$1 \quad$ Introduction}

The Dutch MINeral Accounting System (MINAS) was introduced in 1998, and targeted mineral surpluses from agriculture; the excessive amounts of nutrients that leach from agriculture and cause the pollution of ground and surface waters. The Netherlands is the most intensively livestocked country in Europe and the volume of manure produced constitutes a major environmental problem (MANMF [15]). MINAS was the Dutch government's policy tool for implementing the EU's Nitrate Directive (ND). Thus, the main aim was the reduction of nitrates in groundwater to the World Health Organization safety limit of $50 \mathrm{mg}$ nitrates/liter groundwater (WHO [22]). Nutrient accounting seeks to reduce mineral surpluses from agriculture and to improve the mineral efficiency within the sector. MINAS then combined nutrient accounting with a tax system. MINAS specifically targets nitrogen $(\mathrm{N})$ and phosphate (P2O5), and adopts a farm-gate approach. It thus required the farmer to register all mineral inputs and outputs of the farm, which were reported as $\mathrm{kg}$ of $\mathrm{N}$ and P2O5 in an annual MINAS return. The difference between the mineral inputs and the mineral outputs was assumed to have been lost to the environment on the farm and the farmer was taxed per $\mathrm{kg} / \mathrm{N}$ and $\mathrm{kg} / \mathrm{P} 2 \mathrm{O} 5$ above a 'levy free surplus' (LFS), which represented an admissible level of leaching and one which was environmentally sustainable (Breembroek et al [1]). Figure 1 shows the simple accounting formula behind the system.

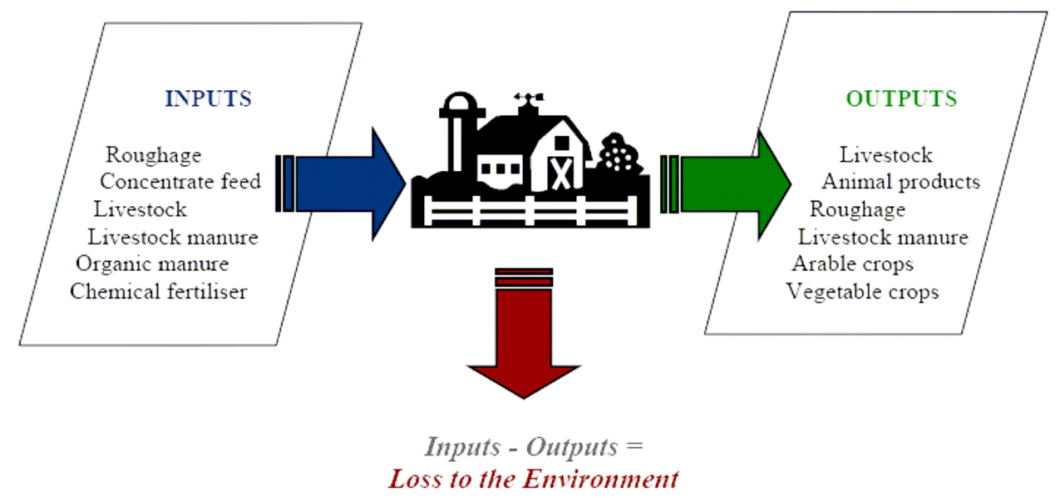

Figure 1: $\quad$ Input and outputs in MINAS (adapted from MANMF [15]).

MINAS adopted a black-box approach and did not take into account minerals within the internal cycle (MANMF [15]). Only manure and crops exported to/from other farms needed to be considered in the MINAS return. Table 1 shows the loss standards for $\mathrm{N}$ and P2O5, according to soil type and land use, together with the tax rates.

The loss standards have been lowered progressively since MINAS was introduced in 1998, and have also become differentiated according to the land type and use (for N). Although based, and taxed, on the calendar year, the 
MINAS system could balance out over a number of years, to cater for the varying situations on the farm from one year to the next. Farmers, whose mineral surplus was under the LFS, could transfer the difference between the LFS and their balance, as an allowance, known as a saldo to be used the following year/years.

Table 1: $\quad$ Loss standards under MINAS in $\mathrm{kg} / \mathrm{Ha}$ and tax rates.

\begin{tabular}{|c|c|c|c|c|c|c|c|c|c|}
\hline \multirow[t]{3}{*}{ Year } & \multicolumn{2}{|c|}{$\begin{array}{l}\mathrm{P}_{2} \mathrm{O}_{5} \text { loss } \\
\text { standard }\end{array}$} & \multicolumn{5}{|c|}{ N loss standard } & \multirow{2}{*}{\multicolumn{2}{|c|}{$\begin{array}{l}\text { Tax Rate } \\
\epsilon / \mathrm{kg}^{16}\end{array}$}} \\
\hline & \multirow[b]{2}{*}{ Arable } & \multirow[b]{2}{*}{ Grass } & \multicolumn{3}{|c|}{ Arable } & \multicolumn{2}{|c|}{ Grass } & & \\
\hline & & & $\begin{array}{l}\text { Clay/ } \\
\text { Peat }\end{array}$ & $\begin{array}{c}\text { Dry } \\
\text { sands }\end{array}$ & Other & $\begin{array}{c}\text { Clay/Peat } \\
\text { Other }\end{array}$ & $\begin{array}{c}\text { Dry } \\
\text { sands }\end{array}$ & $\mathrm{P}_{2} \mathrm{O}_{5}$ & $\mathrm{~N}$ \\
\hline 1998 & 40 & 40 & 175 & 175 & 175 & 300 & 300 & $1.1 / 4.5$ & 0.7 \\
\hline 1999 & 40 & 40 & 175 & 175 & 175 & 300 & 30 & $1.1 / 4.5$ & 0.7 \\
\hline 2000 & 35 & 35 & 150 & 150 & 150 & 275 & 275 & $2.3 / 9.1$ & 0.7 \\
\hline 2001 & 35 & 35 & 150 & 125 & 125 & 250 & 250 & $2.3 / 9.1$ & 0.7 \\
\hline 2002 & 30 & 25 & 150 & 100 & 110 & 220 & 190 & 9.1 & $1.15 / 2.3$ \\
\hline 2003 & 20 & 20 & 100 & 60 & 100 & 180 & 140 & 9.1 & 2.3 \\
\hline
\end{tabular}

Every truckload of manure exported from the farm had to be weighed and sampled by manure transporters with the sample being sent for analysis to an authorized laboratory to establish the mineral content. The $\mathrm{N}$ and P2O5 content of concentrate feed, chemical fertilizer and organic fertilizer (other than manure) were provided by the suppliers. The mineral content in livestock and in animal products was based on government-issued standards, as was that of vegetable products and other crops (MANMF [15]). MINAS allowed high nutrient inputs to the farm, as long as the outputs were correspondingly high, since it was the difference between the two that was taxed.

\section{Empirical basis}

The paper is based on a series of interviews within the following organizations connected with MINAS; The Dutch Ministry of Agriculture, Nature and Food Quality (LNV); Bureau Heffingen (Administrative organization for manure policy); LTO Nederland (The main Dutch Farmers Union); NVV (The Dutch Pig Farmers Union); DLV Advisory Group (Commercial agricultural advisory group); Alterra, Wageningen University and Research Centre; LEI (Agricultural Economics Institute).

\section{Perceived advantages of MINAS vis-à-vis the ND}

MINAS was perceived to have a number of advantages over the ND and appeared to be a better tool for achieving the primary goal of $50 \mathrm{mg}$ nitrate/liter of groundwater. The main measures stipulated within the Nitrate Directive (91/676/EEC) were a manure application standard of $170 \mathrm{~kg} \mathrm{~N}$ organic/hectare/year, mandatory codes of good agricultural practice and the 
designation of nitrate vulnerable zones (NVZ) (EU [11]). In The Netherlands, the whole country was designated an NVZ and the mandatory codes of good agricultural practice were introduced. However, the requirements of the ND were interpreted differently in The Netherlands, with the goal being identified as the reduction of $\mathrm{N}$ per liter of groundwater to $50 \mathrm{mg}$, rather than the achievement of an application standard. Arable and dairy farmers had been used to applying more than $170 \mathrm{~kg} \mathrm{~N}$ from manure/hectare in order to obtain the optimum crop production and thus the imposition of the standard would have reduced the economic productivity of these sectors. However, MINAS did not directly regulate the amount of manure applied to the land; rather it was the amount of mineral losses that were controlled. Indeed, MINAS allowed arable and dairy farmers to apply significantly more nitrogen from manure.

The tax system provided Dutch farmers with an incentive to implement technologies and management practices that increased nutrient efficiency. The system promoted the most cost-effective measures rather than farmers being forced to comply with the application standard, which may have been ineffective in their specific situation. Whereas the ND focused on the input of nutrients through manure, MINAS targeted surpluses, which are the direct cause of the environmental problem and therefore included other sources of nutrients such as artificial feed. Thus, farmers had to be more careful with all sources of nutrients and the tax could not be avoided through the use of substitutes, as would have been the case if the levy were imposed upon fertilizer products.

\section{The erosion of MINAS}

Despite the perceived theoretical advantages of MINAS vis-à-vis the Nitrate Directive many problems were experienced with the system, the following occurring to an excessive extent.

- Financial compensation / refunds made to farmers

- Exemptions made to farmers originally liable to taxation

- Low percentage of tax revenues collected

- Exploitation of loopholes within the system

- Fraud

- Litigation proceedings against the governing authorities

- Refusal amongst target group to pay levies

These problems resulted in an increasing administrative burden for the Levies Office and a corresponding increase in transaction costs in the form of administrative costs. Furthermore, on 2nd October 2003, the European Court of Justice (Case C-322/00) ruled that The Netherlands had "failed to fulfill its obligations under the Directive" (ECJ [8]). MINAS, as a loss standards system, was found to be fundamentally incompatible with the application standard stipulated in the ND. Therefore, MINAS had to be replaced with a new policy in 2006. However, even if the Court of Justice had ruled in favor of MINAS, the problems with the system were so pervasive that MINAS would have had to have been replaced anyway (Personal communication, Oele 2003). 


\section{The uncertainties within the system}

The RIVM report evaluating the Dutch manure policy for the period 1998-2003 (RIVM [19]) describes MINAS as "conceptually well-thought-out", but admits that it involved "too much differentiation and ambivalent numbers" which was unacceptable ([19]:12). This corroborates the view that emerged from the interviews; that a major weakness of MINAS was the uncertainty involved in determining the true mineral content of the various mineral inputs and outputs on the farm (Personal communication, Oele et al. 2003). The uncertainty was due to both biases and errors that occurred as a result of the following.

\subsection{Sampling uncertainty}

The slurry sample was obtained whilst siphoning slurry from the storage pit onto a transport truck. A certain amount of error is inevitable given the inhomogeneous nature of slurry and the large volumes involved. Hoeksma et al [12] found a $16.1 \%$ random error for phosphorous, if the sample was taken during loading, and a $7.1 \%$ error if taken during unloading. Although random errors should theoretically go to zero over time, if these were large and moreover combined with small systematic deviations, sampling errors could give rise to apparent mineral surpluses on the farm.

\subsection{The laboratory analysis}

Manure had to be sent for laboratory analysis to establish its mineral content. The procedure was subject to systematic error in the region of $5 \%$, due to the sedimentation of phosphorous (Personal communication, Oenema 2003). However, there were significant variations in the performance of the certified labs. An investigation (Timmerman et al [23]), which sent a homogenized sample of pig manure to 9 different laboratories established significant variations, up to $26 \%$, in the mineral content calculated.

\subsection{Mineral sedimentation in the manure storage pit}

The slurry on intensive pig farms is collected in a pit, below the stables. The bottom layer of slurry in this pit contains a high concentration of phosphorous, as a result of the sedimentation of this dense compound. This layer was often left in the pit when the manure was removed. This meant that, in these cases, the exported manure contained less phosphorous than the manure which originally entered the pit, and this discrepancy was then assumed to have been lost to the environment on the farm (Timmerman and Smolders [25]).

\subsection{Mineral contents in feed}

Another impediment to the farmer's goal of balancing the inputs and outputs in MINAS was the accuracy of the measurement of the mineral content in animal feed. Despite the error in calculating the mineral content of dry feed by industrial feed suppliers being small, these small errors were the prevalent source of uncertainty. According to Timmerman et al [24], the overall estimated mineral 
content calculated could deviate from the real content due to the deviations in the raw materials used. This could result in less minerals entering the farm than recorded, leading to a deficit in the mineral balance, interpreted as a mineral loss to the environment.

\subsection{The mineral content in pigs}

Standard norms were utilized for the estimation of the mineral content of animal products. These norms were issued by the government, based on scientific studies. However, Jongbloed and Kemme [13], found that the norms used were inaccurate as the original mineral norm was based on the tissue and organ composition of the animal, neglecting other mineral outputs associated with the animal during transport off the farm, e.g. droppings made in transit and the stomach contents (Personal communication, Oenema 2003). The difference in the revised mineral content of the pigs was minimal - about $1 \mathrm{~g} \mathrm{~N}$ and $0.4 \mathrm{~g}$ P2O5per kg/live weight. However, even such small errors could build up when the animal throughput was large (Personal communication, Oenema 2003). A farmer calculating his mineral output based on the original norms, specifying lower mineral contents for both $\mathrm{N}$ and P2O5, appeared to have exported fewer minerals than in reality, thus contributing to a mineral surplus.

\section{The cumulative effect of the uncertainties}

Errors and biases can have significant effects when they occur in a system that is used as a tax where the discrepancy between the total nutrient input and the total nutrient output (over and above the allowed losses) is subject to a levy. MINAS was not a fair system as a farmer who had followed the rules, optimized on-farm efficiency and had legally disposed of the manure produced could still have a large mineral surplus.

Such a surplus was a problem for landless farms, chiefly those in the pig and poultry sectors, which could incur unwarranted levies by virtue of having very little land upon which to spread the manure sustainably and thus practically no permitted surplus, which could absorb the errors, in particular with regards to phosphate. For example, the average pig-fattening farm in The Netherlands with approximately 1000 pig places possesses 5.2 ha of agricultural land. This was equivalent to a total allowed mineral loss of only $520 \mathrm{~kg} \mathrm{~N}$ and $156 \mathrm{~kg}$ P2O5 in 2002 (Table 1). Such farmers had to export their manure. The uncertainties related to determining the mineral content of manure had significant repercussions on the mineral balance for intensive livestock farms, because manure was a large mineral output and thereby magnified the inaccuracies and the size of the unjustified levies.

\section{Contributing factors}

Whilst the occurrence of the unjustified levies was a significant cause of the erosion of MINAS other contributing factors were identified which exacerbated the significance of their financial impact. A significant development occurred in 
1999. The Dutch government increased the tax levies substantially and brought forward the date of the implementation of the final levy-free surplus from 2008 to 2003 (Table 1) by order of the EU Commission who rejected MINAS as being sufficient for tackling the nutrient pollution of groundwater; the original tax levels being too low to provide an adequate economic incentive for farmers (Brinkhorst [2]). This magnified the consequences of the uncertainties considerably with some farmers now receiving very large unjustified levies, which were substantial in some cases, ranging up to 150,000 NGL for pig farmers (€70,000) (Personal communication, Zwanenberg 2003). The farmers that were adversely affected to some degree constituted approximately $50 \%$ of pig producers in The Netherlands (Personal communication, Oele 2003). The unfair levies seriously threatened the viability of some pig producers.

The effect of the unjustified levies was to trigger widespread opposition to MINAS. The intensive pig producers were hardest hit as the costs of MINAS coincided with deteriorating economic performance (LEI [14]), which magnified the financial impact of the costs of MINAS. The radical Dutch pig farmers union (NVV), commissioned a series of investigations into the suspected uncertainties in MINAS (Section 5), the results of which were used by a number of farmers with a mineral surplus to dispute the resultant levies, taking the Dutch government to court. Across the agricultural sector, farmers refused to pay due levies on the basis of the report conclusions and fraud became widespread along with the exploitation of loopholes in the system as farmers became accustomed to MINAS (Personal communication, Oele and Zwanenberg 2003). These events had a dramatic effect on the efficiency of the administrative organization (Bureau Heffingen), which was "drowning in paper" (Personal communication, Zwanenberg 2003).

\section{An increase in complexity and administrative costs}

The concrete manifestation of the widespread resistance was a dramatic increase in the administrative burden due to the increasing complexity of the system, as adjustments were made to address various loopholes, and the sheer number of complaints. Over 11,000 MINAS-related objections and appeals were received by Bureau Heffingen in 2002, accounting for $96 \%$ of the total (Bureau Heffingen, [3]:35). The number of personnel employed at Bureau Heffingen increased significantly since the implementation of MINAS (Figure 2) from approximately 100 in 1996, to 678 in 2001, to cope with the increased workload involved in administering the policy.

The cost of maintaining the policy increased hand-in-hand with the number of personnel. With the implementation of MINAS, the cost was forecast to increase from $€ 12.9$ million in 1996 to $€ 24.2$ million (Ecotec, 2001). The administrative cost of Bureau Heffingen alone was expected to be $€ 12.7$ million. Although budgetary figures for the first years of MINAS were not available, the balance statement of Bureau Heffingen for 2002 shows an expenditure of $€ 52$ million, four times the 1998 estimate (Bureau Heffingen [3]). The forecasted budgets of Bureau Heffingen for 2003 and 2004 indicate persistently high costs of $€ 48$ 
million and $€ 36$ million respectively, of which $€ 28$ million (in 2003) and $€ 25$ million (in 2004) are for the administration of MINAS (Bureau Heffingen, 2003). The administrative costs of MINAS equate to between $60 \%$ and $70 \%$ of the current overall costs, and are double the cost of the whole manure policy in 1998. Due to these high administrative costs, the new Conservative government (CDA) downsized Bureau Heffingen in 2004 (Figure 2) with plans to reduce the administrative costs of manure management policy by $40 \%$ (Personal communication, 2003). The widespread resistance to MINAS within the agricultural sector, the increase in complexity of the system and the dramatic increase in costs, resulted in the serious erosion of the policy;

"We are now in the situation that the whole system is about dead...It's too complicated...there's too much checking, there are too many variabilities in the system... now more farmers are against it, then you have to stop." (Personal communication, 2003)

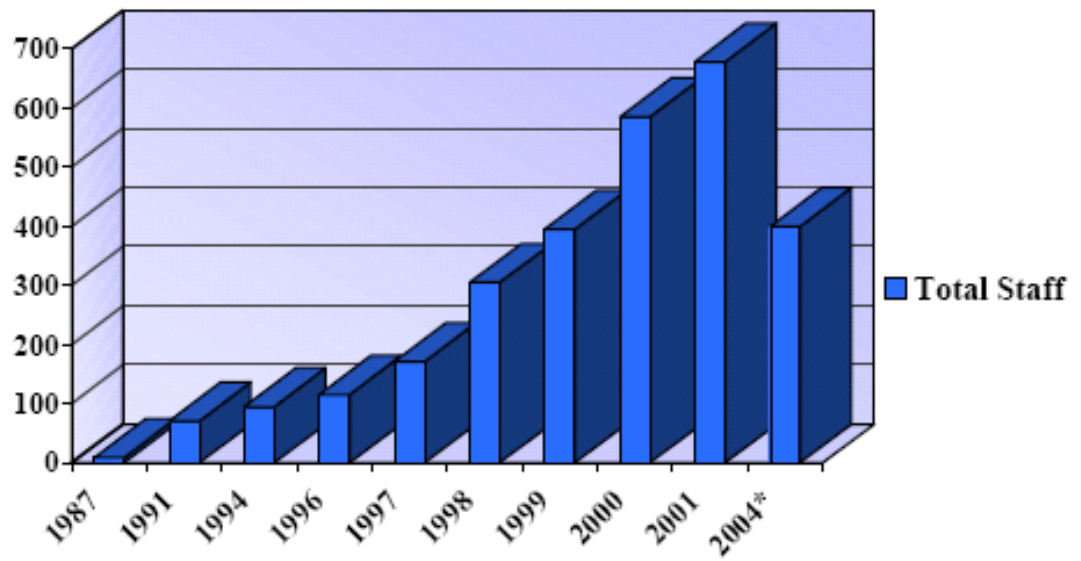

Figure 2: The number of staff employed at Bureau Heffingen (Source: Personal Communication, Oele 2003) *estimated figure.

\section{Do environment taxes involve relatively low transaction costs?}

The MINAS system involved high transaction costs in the form of administrative costs. This is in contrast to what is expected according to the theoretical advantages of environmental taxes (EEA [10]). According to Daugbjerg ([6]:85), when compared to regulations "the implementation of green taxes involves lower administrative costs". However, it is misleading to suggest that all environmental taxes will result in relatively low administrative costs as environmental taxes encompass a broad spectrum of diverse instruments, which vary in their complexity. Recently, there has been an increase in interest in understanding what determines the costs of administering various public policies (Vatn [20]). "A substantial part of transaction costs are related to the costs of demarcating a 
public good" (Vatn [20]:314). Thus, it may be less costly to apply a policy instrument to traded inputs or outputs (private goods) than to the associated public goods or bads, due to the costs of demarcation and the associated costs of observation and control (Vatn [20]:314).

Therefore, a tax on fertilizer inputs is expected to entail very low administrative costs, as it only requires implementation and control at the level of wholesale fertilizer suppliers. Christensen and Hansen [5] report that a tax on all nitrogen inputs is easier to implement than a nitrogen loss tax, such as MINAS, and suggest that the administrative costs of taxing nitrogen loss may be substantially higher than those for taxing nitrogen fertilizer inputs. However, a tax on nitrogen inputs may be too imprecise compared with measures directly attached to the public good one wants to secure or promote, in this case clean water, due to, for example, the possibility for farmers to substitute the taxed nitrogen fertilizer with organic fertilizer. Therefore, in a situation where private and public goods are interconnected in production and transaction costs are positive it may not be rational to have free trade for the private goods while paying separately for the public ones. The transaction costs that are invoked by this solution may by higher than the gains in precision obtained by targeting each policy measure (Vatn [20]:310). In the case of MINAS, the Dutch government expected the system to be costly to administer (Ecotec [9]). MINAS is not a just a tax system, as it is combined with nutrient accounting, the latter necessitating a high degree of administration in an attempt to obtain a high degree of precision, and therefore it is no surprise that it was expensive.

\section{Conclusion}

It is not possible to say that all environmental taxes involve less transaction costs compared with regulatory measures. Whilst a further theoretical advantage of economic instruments vis-à-vis regulations is that they can achieve the environmental target at least cost, as they minimise the total abatement costs across the sector (OECD [16]), it is the total costs of a policy, including transaction costs that matter. The transaction costs involved, may well have a bearing on the final efficiency of an instrument, as with MINAS.

The eventual expense of a proposed tax will depend on its design complexity and the extent of enforcement problems that occur. Thus, the relative administrative cost of taxes vis-à-vis regulations can only be determined on a case-by-case basis. The empirical results support the hypothesis of a correlation between the precision of a policy and transaction costs.

Furthermore, the empirical results indicate that transaction costs can escalate as a result of enforcement costs arising in cases of non-compliance, which necessitate the use of resources to resolve disputes. Enforcement problems can be expected to be more frequent when taxes are introduced against the wishes of certain network actors. This was the case with MINAS, which was implemented against the farmers' wishes, and which the intensive livestock sector in particular considered to target them unfairly by imposing substantial costs without providing any flexibility. 
The incumbent government at the time considered the forecasted transaction costs of MINAS, which involved a high degree of precision, to be worth paying to obtain the environmental improvement. However, the empirical results show that agricultural production systems are far too complex to attempt such extensive control. The sheer complexity of MINAS meant that transaction costs were bound to increase, due to loopholes etc. and it appears that finally these transaction costs became higher than the expected gains from precision. Whilst it may have been possible for policy makers to avoid some of the identified problems, which contributed to the erosion of MINAS, it is considered that the majority were beyond their control and thus it was perhaps inevitable from the outset that such a system would not just become more costly, but infeasible, due to the very high degree of precision that was attempted. Therefore, policy makers could be criticised for not opting for a simpler system.

\section{References}

[1] Breembroek J. A., Koole B., Poppe K. J., and Wossink G. A. A. (1996) 'Environmental Farm Accounting: The Case of the Dutch Nutrients Accounting System', Agricultural Systems 51, (1996) 29-40.

[2] Brinkhorst, L., J. (2000). Vierde voortgangsrapportage mest- en ammoniakbeleid. Tweede Kamer der Staten-Generaal. Vergaderjaar 19992000,24 445 (50), (in Dutch).

[3] Bureau Heffingen (2002). Jaarverslag 2002 (Annual Report) Bureau Heffingen, Assen.

[4] Bureau Heffingen (2003). Activiteitplan. Bureau Heffingen 2004. (Draft dated 24th November 2003)

[5] Christensen, J., Gårn Hansen, L., (2000) Incentive Regulation of Agricultural nitrogen Loss - the Case of Danish Pig Farms. SØM Publication no. 38. AKF Forlaget.

[6] Daugbjerg, C. (2000) 'Explaining Why the Swedes but not the Danes Tax Fertilizers: A comparison of Policy Networks and Political Parties', in Andersen, M. S. and Sprenger, R-U. (Eds). Market-Based Instruments for Environmental Management - Politics and Institutions. Edward Elgar, Cheltenham.

[7] Derikx, P., J., L. (1998). Mineral Book-keeping, New Manure Legislation in The Netherlands. Paper presented at the RAMIRAN 8th International Conference on Strategies for Organic Waste Use in Agriculture, 26th-29th May 1998, France.

[8] ECJ (European Court of Justice) (2003). Judgment of the Court (6th Chamber) 2nd October 2003, Case-C322/00, Failure of a Member State to fulfill its obligations - Directive 91/676/EEC.

[9] Ecotec Research and Consulting (2001) 'Taxes on Fertilizers and Mineral Surpluses', in Ecotec Study on the Economic and Environmental Implications of the Use of Environmental Taxes and Charges in the European Union and its Member States. 
[10] EEA (European Environment Agency) (1996). Environmental Taxes. Implementation and Environmental Effectiveness. Environmental Issues Series 1. EEA, Copenhagen.

[11] European Union (1991). Council Directive 91/676/EEC of 12 December 1991 concerning the protection of waters against pollution caused by nitrates from agricultural sources.

[12] Hoeksma, P., Loeffen, H., and Derikx, P., J., L. (1998). Onderzoek naar de nauwkeurigheid van het VMA-apparaat voor bemonstering van drijfmest op transportwagens. IMAG-DLO, Wageningen. Nota P 98-73

[13] Jongbloed, A. W., Kemme, P. A. (2002). Oriëntatie omtrent de gehalten aan stikstof, fosfor en kalium in landbouwhuisdieren. Rapport ID-Lelystad 2178.

[14] LEI (2000) Think tank on the pig sector. Myths and Sagas about the pig sector. LEI, The Hague.

[15] MANMF (Ministry of Agriculture, Nature management and Fisheries) (2001). Manure and the Environment. The Dutch Approach to Reduce the Mineral Surplus and Ammonia Volatilization. Ministry of Agriculture, The Hague.

[16] OECD (1997). Environmental Taxes and Green Tax Reform. OECD. Paris.

[17] OECD (2003). OECD Environmental Performance Reviews: Netherlands. OECD, Paris.

[18] Ondersteijn, C. J. M. (2002) Nutrient Management Strategies on Dutch Dairy Farms. An Empirical Analysis. PhD Thesis, Wageningen University, The Netherlands

[19] RIVM (2004) Evaluation of the Dutch manure policy 1998-2003 (in Dutch) Available online $\left(30^{\text {th }} \quad\right.$ April 2004) http://www.rivm.nl/bibliotheek/rapporten/500031001.pdf

[20] Vatn, A., (2002). Multifunctional Agriculture: Some Consequences for International Trade Regimes. European Review of Agricultural Economics. Vol. 29 (3) p.309-327.

[21] Veenendaal, P. (2000) Manure: The Final Solution. Radio Netherlands. Available online $\left(12^{\text {th }} \quad\right.$ January 2004) http://www.rnw.nl/hotspots/archive/eur/html/europe000303.html

[22] WHO (2003) Draft Guidelines for Drinking Water Quality, Third edition.

[23] Timmerman, M., Smolders, M. A. H. H. and van Riel, J. W. (2002a) VAR Practical Scientific report 7. Ring census MINAS-laboratories. Wageningen University, Wageningen.

[24] Timmerman, M., Smolders, M. A. H. H. and Verdoes, N. (2002b) VAR Practical Scientific Report 5. MINAS-analysis of the research centers Streksel, Raalte en Rosmalen. Wageningen University, Wageningen.

[25] Timmerman, M., and Smolders, M., A., H., H. (2003). VAR Practical Scientific Report 21. Sediment layers and Manure Sampling of Pig Manure. Wageningen University, Wageningen. 